Anna Grzegorczyk

https://orcid.org/oooo-0002-6280-6275

Uniwersytet im. Adama Mickiewicza w Poznaniu

\title{
Wizja Europy według Edyty Stein ${ }^{1}$
}

\section{Od prawdy filozofów do Boga-Prawdy}

Wizja Europy przekazana nam przez Edytę Stein jest przekonująca i prorocza zarazem, gdy rozważy się ją w kontekście jej dzieł i życia. Jest to bowiem wizja-synteza wywiedziona z filozofii: starożytnej, średniowiecznej, nowożytnej i współczesnej. Kluczem do jej uprzystępnienia jest fenomenologia traktowana jako philosophia perennis, a więc filozofia ramowa, a zarazem otwarta na rozmaite trendy myślowe. Jej zasadniczym rysem jest poznawanie istoty rzeczy. Odkrywanie związków koniecznych tworzących zjawiska, bez których badane fenomeny nie byłyby tym, czym są, a więc związków, które są ich esencjami, istotnościami. Tak rozumiana, najogólniej, fenomenologia jako philosophia perennis otwiera się na różne nurty badawcze, które drążą różne fenomeny od filozofii przedsokratejskiej po czasy współczesne. Inaczej mówiąc, jest to filozofia źródłowa, filozofia poszukująca ostatecznej przyczyny rzeczy, ostatecznego jej jądra, które wypromieniowuje jej sens. Już od starożytności było wiadomo, że ostatecznym ich źródłem jest Absolut, a jego odkrycie związane jest $\mathrm{z}$ dociekaniem prawdy. Rozmaite filozofie, a przede wszystkim te pozostające w kręgu platońskim, wskazywały na Absolut jako ostateczne światło, które nadaje sens wszelkim rzeczom. Platońska filozofia

1 Tekst ten ma charakter źródłowy. Jego wersja znacznie skrócona ukazała się w katalogu do wystawy: W mądrości Krzyża i blasku Zmartwychwstania. Edyta Stein i Maria Hiszpańska Neumann, Poznań 2019. 
światła zagościła jako fundamentalna w philosophia perennis ${ }^{2}$ i została przyjęta przez nurty średniowieczne, np. filozofię św. Augustyna, aż po czasy nowożytne, znajdując w kartezjanizmie swój świadomościowy wariant, a w fenomenologii Edmunda Husserla rozwinięcie w ramach filozofii sensu. Teza Husserla, że rzeczy mają sens (który jest ich istotą) wraz z filozoficznym nakazem „powrotu do rzeczy”, czyli istoty rzeczy, zawraca filozofie po okresie pozytywistycznym do źródła, do philosophiae perennis. Zwrot ten traktowany jest również jako „wydarzenie w kulturze”; nie jest immanentnie rozumianym zwrotem filozoficznym, ale powoduje egzystencjalne „wciąganie” niejako samych fenomenologów w odpowiedzialność i ich otwartość na świat, drugiego i w konsekwencji na Boga ${ }^{3}$.

\section{Filozofowanie ponad granicami}

Droga filozoficzna Stein przekonuje wielu, że mamy do czynienia w jej refleksji ze swoistym połączeniem daru wiedzy i wiary ${ }^{4}$, co w terminach filozoficznej systematyzacji określić można jako fenomenologię egzystencjalną. Wpisana w nią jedność życia i filozofii dopełniona zostaje u Stein przez doświadczenie sacrum - doświadczenie Krzyża. W konsekwencji tej filozoficznej opcji i wyborów życiowych Stein uznaje wiarę za wiedzę pewną i absolutną zarazem, czemu daje wyraz w swej książce Wiedza Krzyż $a^{5}$ i osiąga najwyższe uznanie Kościoła katolickiego: świętość i patronat nad Europą. Można wręcz powiedzieć, że Stein na swej drodze filozoficznej i życiowej usłyszała „wołanie bytu” - wołanie Boga i odpowiedziała na to wołanie darem $z$ siebie. W tym darze mieści się też

2 Szerzej na ten temat piszę w: Filozofia Światła Edyty Stein, Poznań 2004 i w: Ponad kulturami. Uniwersalizm Edyty Stein, Poznań 2010.

3 Fenomenologię jako „wydarzenie w kulturze” traktuje Józef Tischner - zob. J. Tischner, Edyta Stein. Filozof i świadek epoki, red. ks. J. Piecuch, Opole 1997. Por. A. R. Prokop, Eurofilozoficzny kontekst katolickich konwersji pośród fenomenologów, w: Edyta Stein. Europa i jej tożsamość, red. J. Machnacz, T. Marcinów, K. Serafin, Wrocław 2017, s. 50-64; ks. J. Machnacz, Edyta Stein -św. Teresa Benedykta od Krzyża. Osoba, fenomenolog, metafizyk (ontolog), teolog mistyk, świadek (martyr), w: Splendor personae. Święta Edyta Stein - patronka Europy, red. B. Gołkowska, Warszawa 2019, s. $63-94$.

4 Tak syntetycznie ujmuje dzieło i postać Stein np.: Jan Paweł II, Świadectwo błogosławionej Edyty Stein, siostry Benedykty od Krzyża - męczennicy, w: Splendor personae, dz. cyt., s. 21-25; Jan Paweł II, Wiara i Krzyż sq nierozdzielne, w: Splendor personae, dz. cyt., s. 30-32.

E. Stein, Wiedza Krzyża. Studium o św. Janie od Krzyża (Kreuzeswissenschaft. Studie über Johannes vom Kreuz), tłum. I. J. Adamska OCD, G. Sowinski, Kraków 2013. 
odpowiedź na „wezwanie Europy” - odpowiedź, w efekcie wyborów na gruncie wiedzy i wiary, krótka i jednoznaczna: Europa Krzyża. Ta odpowiedź jest filozoficznie i teologicznie docieczona, od czasów starożytnych po współczesne, od teologii Krzyża św. Pawła po jej własną Wiedzę Krzyża $a^{6}$. Filozofia „wzniesiona” do Ewangelii; „prześwietlona” Ewangelią ${ }^{7}$ - to fenomenologia egzystencjalna i partycypacyjna zarazem, w której badacz poznaje rzeczywistość z jednoczesnym uczestniczeniem w niej i życiu sakramentalnym, mistycznie jej doświadcza i jednoczy się z Bogiem. Fenomenologia egzystencjalna i partycypacyjna Stein zbliża się do reguły życia i refleksji karmelitańskiej. Włącza się w jej mądrość i źródłowość. Do jej mistrzów fenomenologicznych (Husserla, Reinacha, Schelera) dołączają w ten sposób święci: św. Paweł, św. Jan od Krzyża i św. Teresa z Avila. Wielka summa Stein Byt skończony a byt wieczny. Wznoszenie się do sensu bytu syntetyzuje dzieje myśli, od ich ukorzenienia w greckich i judaistycznych kręgach, rozwinięcia w filozofii chrześcijańskiej św. Augustyna i św. Tomasza, kartezjańskiej filozofii świadomości, aż po fenomenologiczne jej rozszerzenie - czyniąc osią tej syntezy kategorię prawdy. Droga ta obejmuje odniesienia do prawdy widzianej - aletheia, która jest Absolutem, i prawdy słyszanej - emet, która jest Bogiem-Jahwe, i do prawdy rozumu aż po prawdę istotową i Objawioną - „Prawdę, która cierpi, ale nie ginie” - według słów św. Teresy z Avila ${ }^{8}$ - i refleksję wskazanych świętych, do których Stein się odwołuje.

Ta długa droga do odkrycia prawdy, która jest Prawdą Jedyną, czyli Bogiem w Trójcy Świętej i Prawdą Ukrzyżowaną, jest etapowa, ewolucyjna - jak się zazwyczaj ujmuje: od etapu stricte fenomenologicznego, przez ontologiczny po mistyczny.

I w te etapy wpisują się też jej poglądy na temat Europy. W fenomenologiczny etap: pogląd o Europie jako wspólnocie komunitarystycznej - Europie jako wspólnocie jednostek wolnych i wiernych wartościom uniwersalnym; w etap ontologiczny obraz Europy wywiedziony z jej antropologii filozoficznej;

\footnotetext{
6 Odwołania Stein do św. Pawła są częste, o czym na zakończenie naszej refleksji.

7 Por. J. H. Newman, Ewangelia jako pierwotne źródło ducha ewangelicznego, w: J. H. Newman, Kazania uniwersyteckie, Kraków 2000. Stein znała dzieła Newmana i była ich tłumaczką na język niemiecki.

8 Zob. Święta Teresa od Jezusa, Listy, Kraków 2008, s. 809; por. mój tekst Prawda, która cierpi. Refleksje na temat filozofii mistycznej Edyty Stein, w: Europejskie dziedzictwo Edyty Stein, Wrocław 2005, s. 15-23.
} 
a w etap mistyczny - wizja Europy chrystocentrycznej, prześwietlona jej antropologią teologiczną .

Z perspektywy tego uporządkowania zaskakująca jednak wydać się może zbieżność poglądów Stein z okresu klasycznie fenomenologicznego, ontologicznego i mistycznego. Jest to dla naszej refleksji ważne rozpoznanie, bo wskazuje na moc poznawczą fenomenologii, jej teoriopoznawczy i ontologiczny esencjalizm, który odkrywa istotową tożsamość badanych fenomenów. Zacytujmy, dla poparcia naszej tezy wypowiedź Stein z roku 1918:

Wciąż na próżno staram się zrozumieć, jaką rolę w dziejach świata odgrywamy my, ludzie. Jakiś czas temu zwrócił moją uwagę fragment Ewangelii według św. Łukasza: „Wprawdzie Syn Człowieczy odchodzi według tego, jak jest postanowione, lecz biada człowiekowi, przez którego będzie wydany" [Łk 22, 22]. Czyż nie ma to ogólnego znaczenia? Powodujemy zdarzenia i ponosimy odpowiedzialność. Ale nie wiemy w gruncie rzeczy, co czynimy i nie jesteśmy $\mathrm{w}$ stanie powstrzymać biegu historii, nawet wycofując się z niej. Zrozumieć tego oczywiście niepodobna. Zresztą dla mnie historia i religia zbliżają się do siebie coraz bardziej i zdaje mi się, że średniowieczni kronikarze rozciągający dzieje świata od grzechu pierworodnego po sąd ostateczny byli mądrzejsi od nowoczesnych specjalistów, którym pośród faktów stwierdzonych w sposób nienagannie naukowy zawieruszył się gdzieś sens historii. Te uwagi nie zgłaszają naturalnie żadnych pretensji do naukowości”' ${ }^{\prime \prime}$.

Zauważmy, że dwudziestosiedmioletnia Stein, jeszcze nienawrócona agnostyczka, w korespondencji z Romanem Ingardenem (luty 1918), odwołuje się do wersetu z Ewangelii św. Łukasza i w odniesieniu do niej interpretuje sens historii; i to historii jej współczesnej, obfitującej w ważne wydarzenia polityczne i społeczne. Jej historiozoficzne poglądy, przedzielone dwiema wojnami światowymi, zasadniczo się nie zmienią. Można tę zaskakującą stabilność światopoglądową wyjaśnić poprzez intuicję fenomenologiczną prowadzącą do odkrywania istoty zjawisk; można też, z perspektywy teologicznej, mówić

9 Taki podział drogi filozoficzno-życiowej proponuje m.in. Jerzy Machnacz. Szerzej zob. J. Machnacz, Edyta Stein - św. Teresa Benedykta od Krzyża. Osoba, fenomenolog, metafizyk (ontolog), teolog mistyk, świadek (martyr), dz. cyt., s. 67-88.

${ }^{10}$ List E. Stein do R. Ingardena z 19 II 1918 r., w: Spór o prawdę istnienia. Listy Edith Stein do Romana Ingardena, przeł. M. Klentak-Zabłocka, A. Wajs, Warszawa 1994, s. 58; fragment Ewangelii wg św. Łukasza cyt. przez E. Stein: Łk 22, 22-23. 
o intuicji proroczej, która - włączona w jej egzystencję - wyniosła ją na ołtarze i przyczyniła się do ogłoszenia jej patronką Europy. Jej życie wplecione w trzy byty polityczne: schyłek Cesarstwa Niemieckiego, Republikę Weimarską (1919) i Trzecią Rzeszę podpada pod kwalifikację pograniczności z uwagi na styczność w nim różnych kultur, religii i narodów, ale i europejskości, a także uniwersalnej otwartości. Zaryzykujmy, czyniąc znaczne skróty myślowe, tezę, że jej historiozofia i światopogląd są ponad granicami: filozoficznymi, naukowymi, narodowymi, rasowymi, społecznymi i politycznymi ${ }^{11}$.

\section{Problem człowieka}

Ponad takimi granicami sytuuje się też wizja człowieka Stein. Można ją w ogólności określić jako personalistyczną ${ }^{12}$ I znowu, mimo że porządkując myśl Stein, dzieli się ją na etapy, to wizja ta jest spójna od początku jej filozoficznej drogi aż po ostatni etap. Tę spójność gwarantuje i w tym wypadku właśnie opcja fenomenologiczna, której jest wierna, jak i, generalnie, philosophia perennis ze swą ponadgranicznością i uniwersalnością zarazem. Syntetycznie rzecz ujmując, wpisuje się w antropologię filozoficzną, której personalizm ujawnia się w analizowaniu osoby poprzez odniesienie do Absolutu, jako gwaranta wartości najwyższych, dla którego wykładnią filozoficzną jest Platońska triada; triada zakładających się nawzajem wartości prawdy, piękna i dobra. Stein przyjmuje je jako wartości obiektywne i transcendentne zarazem, umożliwiające trwanie człowieka w jego człowieczeństwie. Człowiek jest osobą, ale horyzont odniesienia jest ponadosobowy. Triadyczny Absolut, jako spadek po starożytnej filozofii zostaje, po konwersji Stein i po anektowaniu filozofii św. Augustyna i św. Tomasza, zastąpiony i zaksjologizowany poprzez kategorię miłości. Grecka aletheia i kalos-agathon w jej filozoficznym dyskursie nabierają atrybutów osobowego Boga, który jest Miłością. Człowiek w antropologii teologicznej Stein zyskuje swe człowieczeństwo poprzez odniesienie do Boga. Jego kondycja jest o tyle ludzka, o ile zostaje przekroczona w kierunku transcendentnym. To ukierunkowanie i jego konkretyzacja zapewnia mu egzystencjalne włączenie w wartości chrześcijańskie i uczestnictwo w życiu sakramentalnym.

${ }^{11}$ Szerzej zob. A. Grzegorczyk, Ponad granicami. Uniwersalizm Edyty Stein, Poznań 2010; A. Grzegorczyk, Europejskie konteksty Edyty Stein, w: Fenomen ducha Europy, Poznań 2010, s. 121-137.

${ }_{12}$ Zob. szczególnie B. Gacka, Personalizm trynitarny Edyty Stein, w: Splendor personae. Święta Edyta Stein - patronka Europy, dz. cyt., s. 129-161 szerzej piszę o problemie w swoim szkicu: Personalizm Edyty Stein wobec współczesnego posthumanizmu, w przywołanym tomie. 
Jego postępująca „personalizacja” gwarantowana jest przez przemiany, które przechodzi w coraz większym otwieraniu się na Boga i podporządkowywaniu wartości ziemskich obiektywnym wartościom transcendentnym. Drogę tych przemian wyznacza okopywanie się w „twierdzy duchowej” - by użyć pojęcia Stein - stanowiącej metaforę poznawania duszy człowieka, a sukcesywne wchodzenie w jej głąb pozwala na zdobycie centrum zamieszkałego przez Boga. To rozpoznanie zapewnia rozbudowanie personalizmu Stein w kierunku antropologii mistycznej. Pokazuje też, na jej gruncie, możliwości osiągania pełni osoby i człowieczeństwa jako unii mistycznej z Bogiem. Niech ten skrót myślowy ujmujący personalizm Stein pozwoli wydobyć bliżej problem człowieka stawiany filozoficznie we współczesnych dla niej kontekstach myślowych, ale będących i dla naszych czasów swego rodzaju orientacją.

Badacze spuścizny naszej filozofki, aby ją przybliżyć i uwspółcześnić, tworzą rozmaite paralele, np. Stein - Dostojewski; Stein - Nietzsche - Weil, Stein Heidegger; Stein - Arendt, Stein - Delsol, Stein- Girard. Te paralele można mnożyć, odwołując się do literatury przedmiotu ${ }^{13}$. Dla nas istotne jest jednak to, że wszystkie one stawiają w centrum rozważań problem człowieka, a w jego tle problem Boga, który Stein opracowuje w szeregu swoich dziel ${ }^{14}$.

Odwołajmy się najpierw do pierwszej paraleli: Stein - Nietzsche - Weil, jako najbardziej dla nas w tym momencie płodnej poznawczo. Vincenzo Nuzzo autor tego zaskakującego zestawienia poglądów ${ }^{15}$, konkluduje, że wszyscy trzej

${ }^{13}$ Zob. M. Buber, Problem człowieka, przeł. J. Doktór, Warszawa 1993; por. A. Grzegorczyk, Cierpienie duszy według Fiodora Dostojewskiego i Edyty Stein, w: Fenomen cierpienia, red. S. Cofta, A. Grzegorczyk, M. Musielak, Poznań 2019, s. 189-211; A. Grzegorczyk, Bóg i wiara w filozofii Edyty Stein, w: Demitologizacja, świadectwo, dialog, dz. cyt., s. 170-201; A. W. Astell, Saintly Mimesis. Contagion, and Empathy In the Thought of Rene Girard, Edith Stein and Simone Weil, "Shofar. An Interdisciplinary Journal of Jewish Studies" 22 (2004) no. 2, s. 116-131; S. Courtine-Denamy, Trzy kobiety $w$ dobie ciemności. Edith Stein, Hannah Arendt, Simone Weil, przeł. G. Przewłocki, Warszawa 2012; R. de Monticelli, Lascese philosophique. Phenomenologie et platonisme, Paris 1997, szczególnie rozdział L'ame, la source et le chateau.

${ }^{14}$ Wymieńmy najważniejsze: E. Stein, Czym jest człowiek? Antropologia teologiczna, przeł. G. Sowiński, Kraków 2012; E. Stein, Budowa osoby ludzkiej. Wykład z antropologii filozoficznej, przeł. G. Sowiński, Kraków 2015.

${ }_{15}$ Zob. V. Nuzzo, Edith Stein ed i filosofi del nostro tempo, Weil e Nietzsche, „Dialegesthai. Rivista telematica di filosofia” 17 (2016) [opublikowany: 30.07.2016 on-line: https://mondodomani. org/dialegesthai/], https://mondodomani.org/dialegesthai/articoli/vincenzo-nuzzo-01 (7.11.2020). Trzeba zauważyć, że Stein nie odwołała się w swych dziełach i listach wprost do Nietzschego, chociaż znała jego filozofię. Słuchała bowiem wykładów Eugena Kühnemanna (1911/1912) poświęconych dziełu i światopoglądowi Nietzschego i uczęszczała na jego seminarium - zob. E. Stein, Dzieje 
myśliciele są twórcami autentycznego odrodzenia metafizycznej religijności, która pozwala wejść im na szczyty ludzkiej myśli, przy czym Nietzschemu i Simone Weil, z uwagi na to osiągnięcie, przypisuje odkrycie dramatycznych, współzależnych i współdziałających ze sobą elementów ducha czasów im współczesnych, natomiast Stein czyni niwelatorką tego dramatyzmu. Zauważmy, że chociaż celem skonstruowania tej odległej paraleli było pogłębienie myślenia Stein, to w rezultacie doszło do apologii refleksji Nietzschego i Weil, $\mathrm{z}$ równoczesnym spłyceniem filozofii autorki Byt skończony a byt wieczny. Wznoszenie się do sensu bytu. Celowo używam w tym momencie pełnego tytułu dzieła Stein, bo z jednej strony jest ono - jak mówiliśmy - jej summą filozoficzną, a z drugiej wskazuje na cel jej drogi myślowo-egzystencjalnej: wznoszenie się do sensu bytu; sensu nadawanego życiu człowieka przez odniesienie go do Boga jako bytu osobowego, który jest miłością. I chociaż wszyscy trzej myśliciele prowadzą dialog filozofii z chrześcijaństwem, jedynie Stein nie gubi się w tragicznych paradoksach metafizyczno-egzystencjalnych. Zawdzięcza to konsekwencji myślowej i życiowej, która czyni jej światopogląd spójnym; światopogląd, w który wpisana jest Prawda Najwyższa i wiedza absolutna, czyli mądrość Krzyża. Podjęcie problemu człowieka włączonego w ten filozoficzny światopogląd pozwala nie tylko odnaleźć człowieczeństwo w człowieku, ale i odkryć Boga, który to człowieczeństwo kształtuje. Nietzsche gubi ten problem, szukając prawdy o człowieku w jego naturalistycznych determinacjach, karząc mu „tańczyć w łańcuchach”16, Paradoksalnie, bo ogłaszając Jego śmierć, równocześnie przyzywa Go, błagając o ponowne Jego przyjście, samemu pogrążając się w nicestwiącej samotności i psychicznej chorobie ${ }^{17}$. Natomiast

pewnej żydowskiej rodziny, przeł. I. Adamska OCD, Kraków 2005, s. 228. Wskazuje na to też fakt wyjaśniania jego filozofii swej siostrze Róży. W Dziejach pewnej rodziny żydowskiej odnotowała wspomnienie: „Przypominam sobie, że Rose zabrała Zaratustrę Nietzschego. Czasem przerywała czytanie i wzywała mnie na pomoc: «Kurczątko, ty jesteś taka mądra, czy możesz mi powiedzieć, co to znaczy?»" (w wydaniu ze Złotej serii na s. 172). Może dystansowała się w ten sposób do jego refleksji; warto pamiętać, że wyraz podobnej niechęci żywiła do Schopenhauera. Gdy wybuchła I wojna, czytała Świat jako wola i przedstawienie i nigdy więcej do tej lektury nie powróciła. W Archiwum Edyty w Kolonii nie ma też śladu zainteresowania Stein filozofią Nietzschego; zob. https://www.karmelitinnen-koeln.de/edith-stein-archiv-kk/gesamtausgabe.

${ }^{16}$ Zob. np. F. Nietzsche, Wędrowiec i jego cień, przeł. K. Drzewiecki, Kraków 2016, s. 260. Żywotność tego przesłania zaznaczają współcześni jego komentatorzy, zob. np. D. Astor, Le tort a ses raisons, „Le Nouveau Magazine Litteraire” $2019 \mathrm{nr}$ 19/4, s. 82-83.

${ }_{17}$ Por. M. Jędraszewski, Tchnąć nowego ducha w Stary Kontynent, w: Fenomen Ducha Europy, Poznań 2010, szczególnie s. 106-107, gdzie autor rozważa kwestię śmierci Boga u Nietzschego i Sartre’a, pokazując pewną gradację problemu: przerażenie odejściem sacrum, ból i odwagę 
Weil, myśląc „przeciw Biblii”, a gloryfikując grecki panteizm, składa uwodzącą, ale nie efektywną ofiarę z siebie i swego myślenia ${ }^{18}$. Wbrew sugestiom autora paraleli, to Stein wspina się na filozoficzne i egzystencjalne szczyty, na które nie wchodzi się „tańcząc w łańcuchach”.

\section{Problem Boga}

Nietrudno w tym momencie dokonać przejścia od problemu człowieka do problemu Boga w refleksji Stein.

Przywołajmy deklaracje filozoficzne Nietzschego o „śmierci Boga” i ich konsekwencje dla wizji człowieka, który ogołocony $\mathrm{z}$ absolutnego, boskiego horyzontu dokonuje przewartościowania wszystkich wartości chrześcijańskich. W tym przewartościowaniu próbuje oprzeć się na samym sobie, na swej woli mocy, która „przymus” - jak pisze - zamienia w zwycięstwo ${ }^{19}$, i która ma umożliwić wykreowanie w przyszłości nadczłowieka, czyli tego, który zajmie puste miejsce po detronizacji Boga. To właśnie z tej koncepcji narodzi się nihilizm europejski, w niej też dla ideologów politycznych znajdzie wsparcie nazizm. Z niej też wywiedzie się rujnującą dla aksjologii koncepcję człowieka wolnego od wszelkich dotychczasowych wartości, która będzie rzutować zarówno na humanistykę, jak i przyrodoznawstwo, dając im światopoglądowe

samotnika po satysfakcję z pozbycia się problemu Boga (Sartre); gradację tę przeprowadza przez odwołanie się do słów Gabriela Marcela: „Jakżeż nie widzieć, że egzystencjalny ton jest tu [u Sartre’a] absolutnie różny, ponieważ zniknęło święte przerażenie i ponieważ zostało ono tutaj zastąpione poprzez satysfakcję człowieka, który usiłuje osadzić swoją doktrynę na ruinach czegoś, w co nigdy nie wierzył” (G. Marcel, L’homme problematique, Paris [1955], s. 32); por. też L. Boros, Bóg człowieka bezradnego, w: L. Boros, Doświadczenie Boga, tłum. B. Tarnas, Warszawa 1983. Nietzsche napisze: „Męczarnie mi zadajesz, szaleńcze,/Katujesz dumę mą?/Miłości daj - któż bo mnie ogrzeje jeszcze?/Któż bo kocha mnie dziś jeszcze? - dłonie daj gorące,/Dajże serc mi panwie żarne, /Mnie najbardziej samotnemu,/Lodu daj. Och! Siedmiokrotnego,/Co wrogów nawet,/Wrogów łaknąć chciwie uczy, /Oddaj, poddaj,/Najokrutniejszy wrogu,/Poddaj mi - si ebie -/Zniknął!/ Oto pierzchnął już,/Ostatni towarzysz jedyny,/Mój wielki wróg,/Mój nieznany,/Mój kat-Bóg! -/ -O nie! O powróć znów!/Z wszystkimi męki swymi!/Do ostatniego z samotników, /O powróć, przyjdź!/Wszystkie źródła moich łez/Do Ciebie płyną wszak!/Ostatni serca mego płomień-/ Tobiezapłonął!/O, powróć, przyjdź,/Nie znany Boże mój! Mój bólu! Me ostatnie - szczęście!” (F. Nietzsche, Tako rzecze Zaratustra, przeł. W. Berent, Nakład Jakuba Mortkowicza, Warszawa 1908, cyt. za L. Boros, Doświadczenie Boga, dz. cyt., s. 86-87).

${ }_{18}$ Por. analizę problemu człowieka, w szczególności w odniesieniu do filozofii Nietzschego, w: M. Buber, Problem człowieka, dz. cyt., s. 35-42.

19 Zob. F. Nietzsche, Wędrowiec i jego cień, dz. cyt., s. 206. 
wsparcie i filozoficzne uzasadnienie. Wizja świata, człowieka i nauki będzie agnostyczna, ateistyczna, liberalna, a w niedalekiej przyszłości dopuszczająca wszelkie aberracje myślowe. W konsekwencji, mimo spektakularnych odkryć naukowych, szczególnie w zakresie technologii i przyrodoznawstwa, nastąpi jak to ujął Martin Buber w nawiązaniu do koncepcji Nietzschego - Gottesfin-

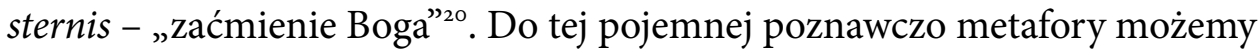
dodać kolejne: „zmieszanie”, „zaćmienie” wartości”, zanik „wielkich narracji”, „płynną tożsamość, upadek wielkich wartości, w tym kategorii prawdy, dobra i piękna aż po metaforę „śmierci człowieka”. Paradoksalnie więc w recepcji myśli Nietzschego nastąpi przejście od „śmierci Boga” do „śmierci człowieka”, a nie do jego wywyższenia do rangi nadczłowieka.

I w tych „zaćmionych” czasach przyszło żyć i działać Stein, która przeżywa nie tylko ciemną noc ludzkości, ale i swą „ciemną noc” mistyczną, której wyraz daje w swym ostatnim dziele - Wiedza Krzyża, analizując etapy wzrostu duchowego św. Jana od Krzyża. I znowu, nie rozwijając tematu, możemy jedynie wskazać, że w odniesieniu chociażby do refleksji i życia takich filozofek jej współczesnych jak Simone Weil czy Hannah Arendt, to ona, a nie one, wspina się w tym przeżywaniu na szczyty filozoficzne i egzystencjalne ${ }^{21}$. I chociaż wszystkie trzy myślicielki poddały analizie kategorię zła, które rozprzestrzeniając się poprzez rozmaite ideologie o proweniencji filozoficznej i naukowej spowodowało „zaćmienie świata, człowieka i Boga”, to właśnie Stein w swej analizie problemu przekroczyła koncepcję „banalności zła” Arendt czy koncepcję „zła jako wykorzenienia” Weil. W swoim rozpoznaniu problemu „zła jako sprzeciwu wobec woli Bożej” pokazała, jak destrukcja horyzontu transcendentnego wyzwala wartości ukierunkowujące człowieka, ale i całe społeczeństwa, na cele przyziemne, naturalizujące jego życie, zacierające granice między mieć i być, wyrzucające go - mówiąc językiem Stein - poza „twierdzę duchową", a w konsekwencji poza jego człowieczeństwo. Wnikliwie pod tym względem analizując Fausta Goethego, odważnie i proroczo pokazuje „zatrute źródło” tkwiące w treści tego arcydzieła literatury, w którym „mieszają” się wartości dobra i zła, pychy i pokory, egoistycznych ambicji i dobroczynnego

${ }^{20}$ Zob. M. Buber, Problem człowieka, dz. cyt.; M. Buber, Zaćmienie Boga, przeł. Lisicki, Warszawa 1994. Zob. szerzej M. Jędraszewski, Tchnąć nowego ducha..., dz. cyt.

${ }^{21}$ Szerzej zob. A. Grzegorczyk, Edyta Stein, Simone Weil i Hannah Arendt wobec zła, w: A. Grzegorczyk, Źródła sensu w humanistyce, Kęty 2018, s. 95-108. 
działania, ludzkiej kreatywności i stwórczej mocy Boga ${ }^{22}$. Metafora dwóch katedr: gotyckiej i renesansowej, do której się odwołuje, ujawnia, dlaczego dzieło Goethego jest treściowo „pęknięte”, „zmieszane”, „zmącone”. Pokazuje bowiem, jak „nieczyste” intencjonalnie wznoszenie budowli w kierun$\mathrm{ku}$ transcendentnym i horyzontalnym, $\mathrm{z}$ nastawieniem przede wszystkim na kunszt artystyczny, a nie duchowe przesłanie, „chwieje” ich architekturą ${ }^{23}$. Również Nietzsche, o dziwo, zauważa elementy chaosu i destrukcji w dziełach Goethego, w tym "pięknie na próżno” - jak pisze ${ }^{24}$. Natomiast według Stein „nieczystość” intencjonalna Goethego ujawnia się - przede wszystkim - w unikaniu autentycznego odniesienia transcendentnego jego dzieła - w braku odniesienia do Chrystusowego Krzyża ${ }^{25}$. Jak pisze: „Nie chodzi tu o niedojrzałą krytykę, ale o ostrzeżenie przed ślepym podziwem, mamy bowiem absolutną miarę, o której nie wolno zapominać, i znak rozpoznawczy, odróżniający naszą drogę od każdej innej. Tym znakiem dla kształtowania naszego człowieczeństwa nie może być jakiś obraz Goethego, lecz krzyż, który chciał ukryć”. I dalej pisze; „Nie znalazł też w swej twórczości miejsca dla idei «grzechu» i «skruchy»"26. Można powiedzieć, że Stein swoją analizą Fausta włącza się w problem Nietzscheańskiego dictum „Bóg umarł” i antycypuje Buberowską diagnozę Gottesfinsternis, a także proroczo antycypuje diagnozę Jana Pawła II w odniesieniu do czasów współczesnych jako „cywilizacji śmierci”.

${ }^{22}$ Por. List św. Jakuba mówiący o zatrutym źródle czy opowieść o budowniczych wieży Babel dotkniętych karą „pomieszania języków”, jako uprzedzających współczesne sytuacje „zmieszanych wartości”.

${ }^{23}$ Zob. E. Stein, Natura i nadnatura w „Fauście” Goethego, w: E. Stein, Twierdza duchowa, przeł. I. Adamska OCD, Poznań 1998, s. 123-135.

${ }^{24}$ Nietzsche napisze: „Można by rzec, iż wiek XIX dążył w pewnym znaczeniu ta kże do tego, do czego dążył Goethe jako jednostka: do uniwersalności w pojmowaniu i wychylnym ocenianiu, do dopuszczenia ku sobie wszystkiego, do zuchwałego realizmu, do czci dla wszystkiego, co rzeczywiste. Skądże to pochodzi, że wynik ogólny to nie żaden Goethe, jeno chaos, nihilistyczne wzdychanie, niewiedza, co począć, jakiś instynkt znużenia, które w praktyce wciąż znagla do naw rotów ku osiemnastemu stuleciu?” (na przykład jako czułostkowa romantyka, jako altruizm i wygórowany sentymentalizm, jako feminizm w smaku, jako socjalizm w polityce - i dalej:) „Czyżby Goethe nie tylko dla Niemiec, lecz i dla całej Europy był jeno epizodem, pięknem na próżno?” (cyt. za: S. Frycz, I.W. Goethe. Szkic portretowy, w: J. W. Goethe, Myśli i uwagi (w rozmowach $z$ Eckermannem), przeł. S. Frycz, Kraków, Drukarnia Eugeniusza i Kazimierza Koziańskich 1912, s. 34).

${ }^{25}$ Szerzej zob. A. Grzegorczyk, Prawda literacka a prawda objawiona w Fauście Goethego i poezji św. Jana od Krzyża, w: A. Grzegorczyk, Obecność wartości, Poznań 2010, s. 47-67.

${ }^{26}$ E. Stein, Natura i nadnatura w „Fauście” Goethego, w: E. Stein, Twierdza duchowa, przeł. I. Adamska OCD, Poznań 1999, s. 132-133. 


\section{Problem Europy}

Można zawyrokować twierdzenie, że Jan Paweł II, czyniąc ze Stein współpatronkę Europy i przeciwstawiając się w swym pontyfikacie „cywilizacji śmierci”, znał jej poglądy filozoficzne (chociaż ich nie cytował), w szczególności odnoszące się do ludzkiej kondycji i Boga. Znał też filozofów, do których się ona pośrednio i bezpośrednio odwoływała. Obdarzając ją patronatem nad Europą z mocy motu propio (1999), odczytał całość jej myślowego dorobku, jak i jej egzystencjalną drogę, jako znak sprzeciwu wobec „prawdy na życzenie”; jako znak sprzeciwu wobec jej relatywizowania, jak i wartości transcendentnych w ogóle. Obrona godności człowieka, mężczyzny i kobiety, a także odnowa horyzontu transcendentnego jako wyjście z cywilizacji śmierci, z „zaćmienia Boga i człowieka" aż do powrotu do źródeł cywilizacji Europy - źródeł biblijnych, greckich i rzymskich, to dziedzictwo, które fenomenologicznie odkryła i jego ożywczą moc ujawniła Stein ${ }^{27}$. Nie będę cytować słów Jana Pawła II w tej kwestii, jako powszechnie znanych. Ich pointa zawiera się w przekonaniu papieża, że Edyta Stein jawi się nam jako dar i nadzieja dla Europy. Wyrażają się one w sprzeciwie wobec wszelkich relatywizmów, bo to one zniesione są przez jej optykę filozoficzną -fenomenologiczną. Optykę ujmującą rzeczywistość w jej głębi źródłowej, esencjonalnej, istotowej i w jej życiu jako świadectwie. Świadectwie wierności odkrytym prawdom objawionym i Prawdzie Jedynej Bogu. Stąd Stein może patronować jedności europejskiej, pod warunkiem, że ta jedność będzie osadzona na chrześcijańskim fundamencie; może patronować nurtom feministycznym, jeżeli będą one wierne naturalnym i duchowym zasadom kierującym życiem kobiety i mężczyzny, które wbrew niektórym interpretacjom, szczególnie feministek i teolożek (zamieszczonym w „L’Osservatore Romano"), nie dadzą się uzgodnić z ideologią gender i LGTB, na co wyraźnie wskazuje jej dzieło Kobieta. Pytania i refleksje ${ }^{28}$. Stąd Stein poprzez swą antropologię filozoficzną i teologiczną może patronować człowiekowi XXI

${ }_{27}$ M. Buber, Problem człowieka, dz. cyt.; A. MacIntyre, Edith Stein. A Philosophical Prologue 1913-1922, Lanham-Boulder-New York-Toronto-Plymouth 2006; G. Weigel, Katedra i sześcian. Europa, Stany Zjednoczone i polityka bez Boga, Poznań 2016; Benedykt XVI, Teologia bez Boga, https://www.vaticannews.va/pl/papiez/news/2019-o8/benedykt-xvi-skandal-naduzyc-reakcjeteologia-bez-boga.htm (20.08.2019).

${ }_{28}$ Zob. np. specjalny numer „L'Osservatore Romano” z 1 września 2014 roku poświęcony „pytaniom kobiet”, szczególnie artykuł Elżbiety Adamiak podnoszący kwestię możliwości zacierania płci między mężczyzną a kobietą - E. Adamiak, Pytania kobiet, https://opoka.org.pl/biblioteka/P/ PR/or20140901-adamiak.html (9.11.2020); por. A. Grzegorczyk, Kobieta Światła i Kobieta Buntu, 
wieku, który, aby uratować swoje człowieczeństwo, winien stać się „człowiekiem mistycznym”; może patronować człowiekowi, który przeciwstawia się technologicznemu jego udoskonalaniu, gdyż technika nie udostępnia żadnej bliskości, a więc nie umożliwia nawiązywania relacji wspólnotowych ${ }^{29}$. Pod jej patronatem nie ma miejsca na „zarazę ateistyczną”, by użyć słów Piusa XI. Wizja Europy Edyty Stein dopowiedziana przez kontekst współczesnych dla niej papieskich encyklik (które zna, zob. np. jej Egzorta na Podwyższenie Krzyża $\mathrm{Z}$ 1941), to obszerny temat ewokowany Listem Stein do papieża Piusa XI z roku 1933 i jej Testamentem z września 1939 roku. Jeśli przywołamy jedynie trzy encykliki Piusa XI: chrystocentryczną Quas Primas (1925), antytotalitarną Mit brennender Sorge (1937) i antykomunistyczną Divini Redemptoris (1938), jak i projekt antyrasistowskiej encykliki Humani Generis unitas ${ }^{30}$, to znajdziemy w nich wszystkie problemy, które poruszała Stein w odniesieniu do tematu Boga, człowieka i Europy, a które zsyntetyzować możemy w podejmowanej przez nas kwestii „zaćmienia Boga” i „zmieszania wartości”. Co więcej, dopiero w ich świetle widać wagę przemyśleń patronki naszego kontynentu, jak i detronizację Boga z równoczesną degradacją człowieka i Europy w czasach jej współczesnych. To w tych encyklikach wprost wybrzmiewają sformułowania o „zarazie laicyzmu”, „zarazie ateizmu”, „zarazie komunizmu i bolszewizmu”, a także o „totalitaryzmie brunatnym i czerwonym” oraz nawoływania o powrót Europy do Chrystusa, aby powrócił pokój i ład w wymiarze społecznym i jednostkowym ${ }^{31}$. W odniesieniu do tych encyklik diagnozy naszych czasów

w: A. Grzegorczyk, Filozofia Światła Edyty Stein, Poznań 2004, s. 228-250; E. Stein, Kobieta. Pytania i refleksje, przeł. W. Szymona OP, Kraków 2015.

${ }_{29}$ Por. odniesienie do Heideggera: „Technika pokonała wszystkie odległości, lecz nie udostępniła żadnej bliskości" (strona główna SMAF - Stowarzyszenia Multimedialnego Archiwum Filozofii).

${ }^{30}$ Por. A. Polewska, Humani Generis unitas - projekt antyrasistowskiej encykliki Piusa XI, https://www.researchgate.net/publication/312649299_Humani_generis_unitas_-_projekt_ antyrasistowskiej_encykliki_Piusa_XI (7.09.2019); zob. też W. Doino Jr, Edith Steins's Letter, https://www.catholicculture.org/culture/library/view.cfm?id=5078 (8.09.2019); J. H. Nota, Edyta Stein a projekt encykliki przeciwko rasizmowi i antysemityzmowi, przeł. J. Zychowicz, "Znak-Idee” $1989 \mathrm{nr}$ 1: Edyta Stein albo filozofia i krzyż, red. P. Taranczewski, K. Tarnowski, H. Woźniakowski, s. 65-80; E. Stein do Joanny van Weersth. List 675, w: Św. Teresa Benedykta od Krzyża/Edyta Stein, Autoportret z listów, cz. 2: (1933-1942), przeł. J. I. Adamska OCD, A. Talarek, Kraków 2003, s. 650.

${ }^{31}$ „Najbardziej przenikliwą analizę słabości stworzonego po 1918 roku ładu pokojowego zaprezentowali kolejni papieże (Benedykt XV, Pius XI oraz Pius XII). Każdy z nich nauczał, że nie będzie trwałego pokoju bez powrotu ludzkości do Chrystusa, bez uznania Jego królowania również w wymiarze społecznym. W tym sensie można powiedzieć, że najpoważniejszą inicjatywą pokojową było ustanowienie przez Piusa XI w 1925 roku święta Chrystusa Króla (encyklika Quas primas) 
w sformułowaniach „zarazy tęczowej” czy „ośmieszeniu się rozumu”32 brzmią łagodnie, ale ewokują grozę, której doświadczyła Stein i miliony ludzi jej epoki. Są to też diagnozy, które apokaliptycznie wyraża w swej antropologii René Girard, chociażby w terminie „zarazy mimetycznej”.

W wizji Europy Stein nie ma bowiem zgody na konsumpcjonizm, na naukę zideologizowaną w kierunku naturalizmu, technologii czy błędnie pojmowanej tolerancji. Powiedzielibyśmy wprost i konkluzywnie: w refleksji Stein nie ma miejsca na człowieka bez Boga, na filozofię bez Boga, na historię, szerzej humanistykę, bez Boga, na politykę bez Boga i na teologię bez Boga. Krótko mówiąc, na świat bez Boga i Europę bez Boga.

Nie pozwala na to jej spójny, chrześcijański światopogląd i filozofia, która fenomenologicznie ujawnia źródła sensu dla człowieka, świata i Europy. Opracowana przez nią filozoficznie metoda wczucia nie tylko przekracza naukowe wyjaśnianie, interpretację czy rozumienie, ale prowadzi poprzez wczucie do pojmowania - najmocniejszego poznawczo i egzystencjalnie aktu metaracjonalnego - świata, człowieka i Boga. Te poglądy Stein ${ }^{33}$ nabierają oczywiście dodatkowego uszczegółowienia w jej spuściźnie ${ }^{34}$. Nie sposób ich tutaj nawet w przybliżeniu wyłożyć. W świetle jednak tego, co już przedstawiliśmy, można zarysować jej wizję Europy, odwołując się do konkretnych wypowiedzi. Poglądy Stein w tym zakresie świadczą o entuzjazmie budowania nowej Europy po I wojnie światowej, po pierwszej traumie XX-wiecznej, po tej pierwszej „próbie ludobójstwa europejskiego" ${ }^{35}$. W liście do Ingardena z 2 czerwca 1918 roku pisze: „Może zainteresuje Pana następujący projekt. Przypomina mi trochę pomysł, z którym sama nosiłam się kiedyś, by w różnych krajach tworzyć

i wezwanie całej ludzkości do uznania Jego społecznego panowania” (G. Kucharczyk, Godzina ciemności. Trwałego pokoju nie będzie bez powrotu do Chrystusa, http://www.pch24.pl/godzinaciemnosci--trwalego-pokoju-nie-bedzie-bez-powrotu-do-chrystusa,70496,i.html\#ixzz5yS3DxEf (9.11. 2020)).

${ }^{32}$ Zob. homilie abp. M. Jędraszewskiego, szczególnie tę z 1.08.2019, https://www.youtube.com/ watch?v=dxFzB2k1HRg (29.12.2020).

33 Por. Jan Paweł II, List apostolski motu proprio Spes aedificandi ogłaszający św. Brygidę Szwedzką, św. Katarzynę ze Sieny i św. Teresę Benedyktę od Krzyża współpatronkami Europy, nr 8, „L'Osservatore Romano” (wyd. pol.) 20 (1999) nr 12 (218), https://opoka.org.pl/biblioteka/W/WP/ jan_pawel_ii/motu/patronki_europy.html (29.12.2020); zob. też Jan Paweł II, Adhortacja apostolska Ecclesia In Europa (28.06.2003), nr 7, https://opoka.org.pl/biblioteka/W/WP/jan_pawel_ii/adhortacje/ europa_28062003.html (29.12.2020).

${ }^{34}$ Por. H. Suchocka, Europa a świadectwo Edyty Stein, „Zeszyty Naukowe Centrum Badań im. Edyty Stein” 2014 nr 11: Fenomen Edyty Stein. Das Phänomen Edith Stein, s. 345-355.

35 J.-M. Domenach, Europa: wyzwanie dla kultury, przeł. H. Sikorska, Warszawa 1992, s. 121-133. 
instytuty do spraw «wymiany kulturalnej», które służyłyby zadzierzgnięciu wzajemnego porozumienia. Wprawdzie wygląda to tak, jak gdyby przede wszystkim chodziło o kwestie gospodarcze, ale przecież od pracujących tam ludzi będzie zależało, jaki kształt nadadzą tej sprawie. Według mnie powinni to być nie tylko wybitni uczeni niemieccy, których i dawniej nigdy nie brakło, a którzy jednak nie umieli przekazać dostatecznej wiedzy o zagranicy, lecz także reprezentanci dawnych krajów. I tak, na przykład w przypadku historii Polski i literatury polskiej życzyłabym sobie koniecznie Polaka. Ewentualnymi niedostatkami «obiektywizmu» już by się zajęli nasi profesorowie. Nie chodzi przecież w tym przypadku tylko o to, jak było naprawdę, ale wręcz bardziej o to, jak wyglądało to z drugiej strony. Proszę się rozejrzeć, czy znaleźliby się u was odpowiedni ludzie. Może dałoby się zrobić coś w tej sprawie"36. Ta wizja i ten entuzjazm uwidacznia się w jej pracach, takich jak Jednostka i wspólnota czy Naród i państwo ${ }^{37}$. Jest ona korygowana przez historyczne okoliczności, ale istotowo w odniesieniu do problemu człowieka, społeczeństwa, historii i Boga pozostaje zasadniczo niezmieniona. Alasdair MacIntyre rekonstruuje ją w duchu komunitaryzmu, biorąc pod uwagę wskazywane przez nią relacje państwa do norm etycznych i wartości. „Nie jest ona kontrakcjonistką - pisze o Stein. Nie stoi też na stanowisku liberalnym, zgodnie z którym państwo powinno być neutralne i bezstronne wobec rywalizujących koncepcji życia moralnego" ${ }^{38}$. Nie zgadza się też z Heglowską koncepcją państwa, bowiem, Stein uważa, że państwo ma wprawdzie historię moralną, lecz jest to historia jednostek działających poprzez państwo. „Wolności, nadawane przez państwo i rządy prawa, są w efekcie same zakorzenione w wolnej podmiotowości jednostek, które nadają im byt i je konserwują" 39 , bowiem "moralny charakter państwa i jego obywateli instytucje państwa ujawniają raczej poprzez otwartość na pełen wymiar wartości" ${ }^{\prime \circ}$.

Przypominając w tym momencie historiozoficzny pogląd Stein o odniesieniu historii dziejów do Transcendencji i odwołując się do jej antropologii

${ }^{36}$ List E. Stein do R. Ingardena z 2.06.1918 r., w: Św. Teresa Benedykta od Krzyża/E. Stein, Autoportret $z$ listów, cz. 3: Listy do Romana Ingardena, przeł. M. Klentak-Zabłocka, A. Wajs, Kraków 2003, s. 121; zob. Spór o prawdę istnienia, dz. cyt., s. 72.

${ }^{37}$ Por. A. Gniazdowski, Komunitaryzm Edyty Stein wedtug Alasdaira MacIntyre'a, w: Wobec doświadczenia. Fenomen Edyty Stein, cz. 2, red. A. Grzegorczyk, M. Grzywacz, P. Jakubowski, R. Koschany, Poznań 2017, s. 121-123.

${ }^{38}$ A. MacIntyre, Edith Stein..., dz. cyt., s. 96.

39 A. MacIntyre, Edith Stein..., dz. cyt., s. 96.

${ }^{40}$ A. MacIntyre, Edith Stein..., dz. cyt., s. 96. 
teologicznej, można powiedzieć, że jej wizja Europy podporządkowana jest chrześcijaństwu Krzyża; że w jej ostatnich dziełach jest to wyraźnie i mocno zaznaczone.

Wystarczy w tym momencie przywołać nasze wcześniejsze paralele, aby wprost powiedzieć, że wizję tę określają wielkie symbole katedry i krzyża. W ich kontekście ujawnia swą moc zarówno mądrościowa „wiedza Krzyża”, jak i wielkość katedry, która symbolizuje świat zaślubiony z Transcendencją ${ }^{41}$. Katedry symbolizującej „wieczną katedrę”, wznoszoną „Tworzącą Ręką Boga”, „wznoszącą się z ziemi ku niebiosom” - jak mówi w poemacie Kim jesteś, słodkie Światło ${ }^{42}$. Kultura i Transcendencja, ucieleśniona w katedrze, poświadcza tożsamość Europy i nadaje europejskie obywatelstwo, również „obywatelstwo niebieskie”, bo jak mówi Stein, w Egzorcie z 1941 roku, za Ewangelistą - św. Pawłem: „Nie mamy tu miasta trwałego” (Hbr 13, 14). Co więcej, moglibyśmy zaktualizować wizję Stein, która mówi o „płonącym świecie”, przez odniesienie do płonącej Katedry Notre Dame, nie dodając zbędnych w tym momencie komentarzy.

W tej proroczej wizji znajdują swe odniesienia wizje Europy budowane współcześnie przez George’a Weigela, Chantal Delsol czy René Girarda, dystansujące się od Europy głoszącej „przegraną Boga”, jak i wskazujące wyjście

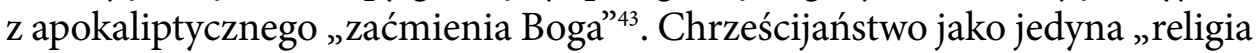
z krzyżem” wśród religii świata ${ }^{44}$ jest gwarantem nie tylko tożsamości Europy, ale i człowieka, i świata w ogóle. Krzyż jawi się w tych rozwinięciach i jako cierpienie, i jako zbawienie Europy. Stein jest przekonana nie tylko, że „Żadne dzieło duchowe nie rodzi się bez cierpienia”, lecz także, że żaden człowiek i żadna wspólnota nie przetrwa i nie zbawi się bez Krzyża. „Jeśli niesiesz Krzyż, to On niesie ciebie i on cię zbawia" - przekonuje w wierszu U stóp Krzyża

${ }^{41}$ Por. ks. M. Tatar, Europa bez krzyża - krzyż przyszłością Europy, w: Splendor personae. Święta Edyta Stein - patronka Europy, dz. cyt., s. 103-128.

${ }^{42}$ E. Stein, Qui es-tu, douce Lumière, w: E. Stein, Malgré la nuit: poésies complètes, trad. C. Rastoin, Genève 2002, s. 121-129; por. E. Stein, A ja pozostaję z wami. Z nowenny na Zesłanie Ducha Świętego, przeł. Zbigniew Naumowicz, w: J. I. Adamska OCD, Mądrość Miłości, Tczew-Peplin 1998, s. 256-259.

${ }^{43}$ Por. S. Quinzio, Przegrana Boga?, przeł. M. Bielawski, Kraków-Dębica 2008, s. 41; zob. np. Ch. Delsol, Kamienie węgielne. Na czym nam zależy?, przeł. M. Kowalska, Kraków 2018; R. Girard, Apokalipsa tu i teraz, przeł. C. Zalewski, Kraków 2018; J. Kopania, M. Nowacka, Od unieśmiertelniania człowieka do śmierci cywilizacji, w: Ulepszanie człowieka. Perspektywa filozoficzna, red. G. Hołub, P. Duchliński, Kraków 2018, s. 31-71.

${ }^{44}$ Por. H. Waldenfels, Ukrzyżowany i religie świata, przeł. P. Pachciarek, Warszawa 1985. 
w myśl Juxta Crucem te cum stare $!^{45}$. W perspektywie Stein europejska walka z Krzyżem to nie zdobycz cywilizacyjna, lecz upadek Europy, a zarazem budowanie Europy jako „cywilizacji śmierci”. Wizja Europy Stein, jako „Europy pod Krzyżem”, uwidacznia się chociażby we współczesnej ideologicznej walce „przeciw Krzyżowi” (bezczeszczenie Krzyża, symboli sakralnych), aż po apel odnoszący się do niedawnej tragedii na Giewoncie. Riposta na przekonanie, że „trzeba usunąć Krzyż, który zabija”, może być wywiedziona, między innymi, z wiedzy Krzyża i doświadczenia Krzyża samej Stein i czasów jej współczesnych. Patronka Europy pisze: „Krzyż stał się znakiem sprzeciwu. Zwolennicy Antychrysta znieważają go gorzej niż Persowie, którzy go niegdyś zrabowali. Profanują bowiem wizerunki krzyża i usiłują ze wszystkich sił wydrzeć krzyż z serc chrześcijan. Udaje się to im nawet wobec osób, które podobnie jak my, ślubowały, że poniosą krzyż za Chrystusem" (Egzorta z 1939).

W nawiązaniu do tej wypowiedzi można powiedzieć, że to nie krzyż zabija, lecz czynią to rozmaite ideologie, którym człowiek ulega; również słowo może zabić, szczególnie słowo filozofa. Riposta ta ma też swe uzasadnienie w odwołaniu się wprost do refleksji Nietzschego; do jego stwierdzenia o „śmierci Boga” i do przeświadczenia, że człowiek to ten, który „zabił swego Boga”.

\section{Testament duchowy Stein: Ave Crux, spes unica!}

Witaj Krzyżu, jedyna nadziejo! Witaj Europo w Krzyżu, z Krzyżem i poprzez Krzyż, jedyna nadziejo! - to wizja Steinowskiej Europy. A więc Europa zjednoczona poprzez Krzyż, poprzez Kościół o podwalinach opartych na fundamencie teologii Krzyża, któremu patronuje św. Paweł, do którego Stein często się odwoływała. Pisała między innymi: „Dusza zjednoczona z Chrystusem żyje Jego życiem przez oddanie się Ukrzyżowanemu, przez przejście z Nim całej drogi krzyżowej. Nikt nie powiedział tego jaśniej i dobitniej niż św. Paweł. On posiadł całą wiedzę krzyża i rozwinął w teologię krzyża, czerpiąc z własnego, najbardziej wewnętrznego doświadczenia" ${ }^{46}$. Ona też odwoływała się do roli wiary, która przemienia grzesznika i go dźwiga ku świętości: „Wielki ciężar trzeba dźwigać i tylko wiara silna jak skała jest zdolna go unieść. Dopiero w ostatnich miesiącach wzięłam do rozmyślania Dzieje Apostolskie, a obecnie jestem przy Listach. Dlatego w tym roku to podwójne święto (śś. Piotra i Pawła)

${ }^{45}$ Zob. E. Stein, Le signe de la Croix i Au pied de la Croix, w: Malgré la nuit, dz. cyt., s. 65-71; $79-83$.

${ }^{46}$ E. Stein, Myśl na 25 stycznia, w: Myśli Edyty Stein, wybór M. Hoffmann, Warszawa 1995, s. 18. 
będę przeżywała z uczuciem szczególnej miłości dla obydwu mocnych filarów świętego Kościoła. Jaką bezmierną skarbnicą jest Pismo Święte" ${ }^{\text {"4 }}$.

W tym momencie można już wnosić, jak ważna dla naszych rozważań okazuje się wskazana na początku paralela: św. Paweł i Edyta Stein, a więc Apostoł Pojednania Narodów i Patronka Europy. Zarówno dla św. Pawła, jak i dla Stein Ewangelia jest busolą finału ich drogi życiowej i filozoficznej. Teologia Krzyża św. Pawła jest podstawą, na której buduje swoją wersję „wiedzy Krzyża” („Kreuzeswissenschaft” można też tłumaczyć jako mądrość Krzyża). I św. Paweł, i Stein - św. Teresa Benedykta od Krzyża ${ }^{48}$, a także św. Jan od Krzyża wraz z Teresą z Avila mają jedno przesłanie dla człowieka, świata i Europy: dźwiganie Krzyża, bo w nim jest prawda, która cierpi, ale nie ginie. Filozoficzna i życiowa droga łączą się w prawdzie Krzyża; w niej jednoczy się człowiek z Bogiem i drugim człowiekiem.

Z tą prawdą łączy się też, bliskie wizji Europy Edyty Stein, przesłanie Cypriana K. Norwida, który w poetyckiej wizji zagrożenia wartości transcendentnych zapytuje: „Gdzież się podział krzyż?” i odpowiada: „Stał się nam bramą!”49.

${ }^{47}$ E. Stein, Myśl na 29 czerwca, w: Myśli Edyty Stein, dz. cyt., s. 6o.

${ }^{48} \mathrm{~W}$ tej wersji szkicu pomijam paralelę św. Benedykt i św. Edyta Stein.

49 «Ojcze mój, twa łódź

Wprost na most płynie -

Maszt uderzy!... Wróć!

Lub wszystko zginie.

Patrz, jaki tam krzyż,

Krzyż niebezpieczny!

Maszt się niesie wzwyż,

Most mu poprzeczny».

«Synku, trwogi zbądź!

To znak zbawienia;

Płyńmy, bądź co bądź!

Patrz, jak się zmienia!

Oto wszerz i wzwyż

Wszystko toż samo».

«Gdzież się podział krzyż?»

«Stał się nam bramą!»

(C. K. Norwid, Krzyż i dziecko, w: C. K. Norwid, Pisma wybrane, t. 1: Wiersze, Warszawa 1980, s. 398-399). Na temat wspólnej duchowej perspektywy Stein i Norwida zob. R. Brasse, Gajcy, Norwid - liryczne kreacje z perspektywy duchowości Edyty Stein, w: R. Brasse, Poetyka doświadczenia duchowego w liryce Gajcego, Toruń 2018, s. 285-305. 


\section{Konkluzje}

1. Fenomenologia jako philosophia perennis stanowi podstawę refleksji Stein. Gwarantuje otwartość, bezgraniczność i uniwersalność jej przemyśleń filozoficznych. Metaforycznie można powiedzieć, że pozwala jej wzlatywać jak orzeł ponad granią kultur, religii, ras, narodów, a także pojąć fenomen człowieka i Boga; pozwala także ukorzyć się przed wpisaną w niego tajemnicą, a wiarę przyjąć za najwyższy poziom wiedzy; wiedzy, która nie jest ani wyjaśnianiem, ani interpretacją czy rozumieniem, ale pojmowaniem, najwyższym aktem poznawczym, do którego zdolny jest człowiek.

2. Proroctwo Stein: „Zaćmienie Europy” - „nieczystość” intencjonalna działań człowieka i społeczeństw ujawnia się przede wszystkim w unikaniu autentycznego odniesienia ich do Transcendencji, w braku odniesienia do Chrystusowego Krzyża (paralela Goethe - Nietzsche - Arendt).

3. Nietzsche zapytuje: „Czyżby Goethe nie tylko dla Niemiec, lecz i dla całej Europy był jeno epizodem, pięknem na próż no?” i przekonuje: „Człowiek zabił swego Boga”, ale nie dodaje, że słowo filozofa również zabija.

Zaświadczają to dzieje ponietzscheańskiej filozofii i dalsze konstruowane paralele z myślą Stein, np. paralela z Heideggerem, z której wychodzi nasza filozofka zwycięsko. „Ciemnej filozofii” Heideggera, jak ją sama nazywa, rzuca wyzwanie otwierające zaryglowane przez niego drzwi przed Transcendencją. Nie lęka się filozofować w obliczu Boga. Jest to jej odpowiedź na Heideggerowskie ucieczkowe przekonanie: „Bóg nie filozofuje”

4. Wizja Europy, wizja świata, wizja człowieka według Stein jako teocentryczna wraca do początku, do myślenia religijnego, do źródeł, z których człowiek czerpie sens swego i świata istnienia. Zacytowana przez nas na początku szkicu Ewangelia św. Łukasza, którą przywołuje Stein („Wprawdzie Syn Człowieczy odchodzi według tego, jak jest postanowione, lecz biada człowiekowi, przez którego będzie wydany"), wraz z odwołaniami do świętych (w szczególności św. Pawła i Piotra), prześwietlają jej dzieło i nadają sens kreślonej przez nią wizji Europy. Wizyjność św. Pawła ${ }^{51}$ i św. Teresy Benedykty od Krzyża

${ }^{50}$ Szerzej zob. A. Grzegorczyk, Stein contra Heidegger, w: A. Grzegorczyk, Obecność wartości, Poznań 2010, s. 179-186.

${ }^{11}$ Szerzej zob. E. Dąbrowski, Dzieje Pawła z Tarsu, Warszawa 2013; https://teologiapolityczna. pl/ks-eugeniusz-dabrowski-sw-pawel-w-atenach; https://teologiapolityczna.pl/ks-eugeniuszdabrowski-przed-bramami-damaszku; http://biblista.pl/ukryte/czytelnia-biblijna/4456-jezus-ipawe-ks-h-witczyk.html (2.09.2019). 
zaświadczona $\mathrm{w}$ ich pismach i życiu stanowi bliską paralelę, która wyraża się w ich chrystocentryzmie; we wskazaniu na Prawdę, Drogę i Życie, którą jest Chrystus - za Nim należy podążać, aby sens świata, Europy i człowieka jawił się jako jedyny i oczywisty. Przy podjęciu takiego wyzwania Europa, jak przekonywała Stein i nadal temu przekonaniu patronuje, Bóg nie przegrywa można by dać wprost odpowiedź Sergiowi Quinziowi ${ }^{52}$. Wyjściem $\mathrm{z}$ „ciemnych czasów” Stein, jak i naszych współczesnych jest konieczność pójścia za Nim, a nie przed Nim. „Zaćmienie Boga” w jej epoce, jak i naszej, spowodowane zostało przez przedkładanie człowieka nad Boga.

5. Możliwość „pojednania światów”, które głosił św. Paweł, i „pojednania Europy”, o które zabiegała Stein, jest realna w chrześcijaństwie opartym na wiedzy Krzyża. „Co do mnie, nie daj Boże, bym się miał chlubić z czego innego, jak tylko z krzyża Pana naszego Jezusa Chrystusa, dzięki któremu świat stał się ukrzyżowany dla mnie, a ja dla świata" $(\mathrm{Ga} 6,14)^{53}$. To przekonanie św. Pawła w pełni przyjmuje Edyta Stein, odwołując się często do głoszonego przez niego słowa Bożego, szczególnie w Wiedzy Krzyża. Z uwagi na te odwołania i świadectwo podjętej drogi Żyd z Tarsu i Żydówka z Wrocławia stają się apostołami Miłości, Pojednania i Nadziei dla świata i wzmocnienia chrześcijańskich fundamentów Europy.

6. Wizja Europy Stein ukazana przez odniesienie do paraleli filozoficznych, literackich i religijnych winna być ujmowana także w kontekście współczesnych dla niej papieskich encyklik Piusa XI: chrystocentrycznej Quas Primas (1925), antytotalitarnej Mit brennender Sorge (1937) i antykomunistycznej Divini Redemptoris (1938), jak i projektu antyrasistowskiej encykliki Humani Generis unitas. W ich świetle dają się zsyntetyzować podejmowane problemy „zaćmienia Boga” i „zmieszania wartości”. Co więcej, dopiero w ich świetle

52 Zob. S. Quinzio, Przegrana Boga?, dz. cyt.

53 Święty Paweł: „11 Przypatrzcie się, jak wielkie litery własnoręcznie stawiam ze względu na was. 12 O ludzkie to względy ubiegają się ci wszyscy, którzy was zmuszają do obrzezania; chcą mianowicie uniknąć prześladowania z powodu krzyża Chrystusowego. 13 Bo ci zwolennicy obrzezania zgoła się nie troszczą o zachowanie Prawa, a o wasze obrzezanie zabiegają tylko dlatego, by się móc pochwalić waszym ciałem. 14 Co do mnie, nie daj Boże, bym się miał chlubić z czego innego, jak tylko z krzyża Pana naszego Jezusa Chrystusa, dzięki któremu świat stał się ukrzyżowany dla mnie, a ja dla świata. 15 Bo ani obrzezanie nic nie znaczy ani nieobrzezanie, tylko nowe stworzenie. $16 \mathrm{Na}$ wszystkich tych, którzy się tej zasady trzymać będą, i na Izraela Bożego [niech zstąpi] pokój i miłosierdzie! 17 Odtąd niech już nikt nie sprawia mi przykrości: przecież ja na ciele swoim noszę blizny, znamię przynależności do Jezusa. 18 Łaska Pana naszego Jezusa Chrystusa niech będzie $\mathrm{z}$ duchem waszym, bracia! Amen" (Ga 6, 11-18). 
widać wagę przemyśleń patronki naszego kontynentu, jak i detronizację Boga z równoczesną degradacją człowieka i Europy w czasach jej współczesnych. W odniesieniu do tych encyklik diagnozy naszych czasów w sformułowaniach „zarazy tęczowej” czy „ośmieszenia się rozumu” brzmią łagodnie, ale ewokują grozę, której doświadczyła Stein i miliony ludzi jej epoki.

7. Pod słowami Piusa XI: „Nie ustajemy również modlić się i wołać za prześladowcami ciemiężycielami, aby Ojciec wszelkiego światła i zmiłowania oświecił ich, jak Pawła w drodze do Damaszku, i tych wszystkich, którzy wraz z nim i z nimi błądzili i błądzą”, mogłaby podpisać się nie tylko Stein... Utożsamiamy się z nimi i my - współcześni, prosząc ją o patronowanie „bezbożnej” Europie ${ }^{54}$.

\section{ABstrakt}

Artykuł jest syntetycznym ujęciem wizji Europy z perspektywy fenomenologii traktowanej jako philosophia perennis zaproponowanym przez Edytę Stein / św. Teresę Benedyktę od Krzyża. Obejmuje następujące zagadnienia: absolutny charakter prawdy, uniwersalność filozofii, elementy antropologii personalistycznej, odpowiedź na Nietzscheańską „śmierć Boga”, odpowiedź na „cywilizację śmierci” oraz Krzyż jako nadzieja. Główne wnioski są zreasumowane w siedmiopunktowej konkluzji.

\section{SŁOWA KLUCZOWE}

Stein Edyta, Teresa Benedykta od Krzyża, Europa, „zaćmienie Europy”, fenomenologia, Nietzsche Fryderyk, Heidegger Martin, teocentryzm, personalizm

\section{ABSTRACT}

\section{Stein's Vision of Europe.}

The article is a synthetic approach to the vision of Europe from the perspective of phenomenology treated as philosophia perennis proposed by Edith Stein / St. Teresa Benedicta of the Cross. It covers the following issues: the absolute character of truth, the universality of philosophy, elements of personalist anthropology, the answer to the Nietzschean "death of God," the answer to the "civilization of death" and the Cross as Hope. At the end of this study there is a seven-point conclusion.

54 Zob. Encyklika Papieża Piusa XI do czcigodnych braci arcybiskupów i biskupów Niemiec i innych ordynariuszy, utrzymujących pokój i jedność ze Stolica Apostolską „Mit brennender Sorge”. O położeniu Kościoła w III Rzeszy. 14.III.1937 r., Warszawa 2002, s. 20; warto zauważyć, że Pius XI w tej tylko encyklice odwołuje się 10 razy do wypowiedzi św. Pawła. 


\section{KeYWORDS}

Edith Stein, Teresa Benedicta of the Cross, Europe, “eclipse of Europe”, phenomenology, Friedrich Nietzsche, Martin Heidegger, theocentrism, personalism

\section{BIBLIOGRAFIA}

Adamiak E., Pytania kobiet, https://opoka.org.pl/biblioteka/P/PR/or20140901-adamiak.html (9.11.2020).

Astell A. W., Saintly Mimesis. Contagion, and Empathy In the Thought of Rene Girard, Edith Stein and Simone Weil, „Shofar. An Interdisciplinary Journal of Jewish Studies” 22 (2004) no. 2, s. 116-131.

Astor D., Le tort a ses raisons, „Le Nouveau Magazine Littéraire” 2019 num. 19-20, s. $82-83$.

Benedykt XVI, Teologia bez Boga, https://www.vaticannews.va/pl/papiez/news/2019o8/benedykt-xvi-skandal-naduzyc-reakcje-teologia-bez-boga.htm (20.08.2019).

Boros L., Bóg człowieka bezradnego, w: L. Boros, Doświadczenie Boga, tłum. B. Tarnas, Warszawa 1983.

Brasse R., Gajcy, Norwid - liryczne kreacje z perspektywy duchowości Edyty Stein, w: R. Brasse, Poetyka doświadczenia duchowego w liryce Gajcego, Toruń 2018, s. 285-305.

Buber M., Problem człowieka, przeł. J. Doktór, Warszawa 1993.

Courtine-Denamy S., Trzy kobiety $w$ dobie ciemności. Edith Stein, Hannah Arendt, Simone Weil, przeł. G. Przewłocki, Warszawa 2012.

Dąbrowski E., Ateny w pierwszym wieku ery chrześcijańskiej, https://teologiapolityczna. $\mathrm{pl} /$ ks-eugeniusz-dabrowski-sw-pawel-w-atenach (9.11.2020).

Dąbrowski E., Dzieje Pawła $z$ Tarsu, Warszawa 2013.

Dąbrowski E., Przed bramami Damaszku, https://teologiapolityczna.pl/ks-eugeniusz-dabrowski-przed-bramami-damaszku (9.11.2020).

Delsol Ch., Kamienie węgielne. Na czym nam zależy?, przeł. M. Kowalska, Kraków 2018.

Die Texte der Edith Stein - Gesamtausgabe, https://www.karmelitinnen-koeln.de/ edith-stein-archiv-kk/gesamtausgabe (7.11.2020).

Doino W., Jr., Edith Steins's Letter, https://www.catholicculture.org/culture/library/ view.cfm?id=5078 (8.09.2019).

Doino W., Jr., Edith Steins's Letter, https://www.catholicculture.org/culture/library/ view.cfm?id=5078 (8.09.2019).

Domenach J.-M., Europa: wyzwanie dla kultury, przeł. H. Sikorska, Warszawa 1992.

E. Stein do Joanny van Weersth. List 675, w: Św. Teresa Benedykta od Krzyża/Edyta Stein, Autoportret z listów, cz. 2: (1933-1942), przeł. J. I. Adamska OCD, A. Talarek, Kraków 2003, s. 650. 
Encyklika Papieża Piusa XI do czcigodnych braci arcybiskupów i biskupów Niemiec i innych ordynariuszy, utrzymujących pokój i jedność ze Stolica Apostolska „Mit brennender Sorge”. O położeniu Kościoła w III Rzeszy. 14.III.1937 r., Warszawa 2002.

Frycz S., I.W. Goethe. Szkic portretowy, w: J. W. Goethe, Myśli i uwagi (w rozmowach $z$ Eckermannem), przeł. S. Frycz, Kraków: Drukarnia Eugeniusza i Kazimierza Koziańskich 1912, s. 5-34.

Girard R., Apokalipsa tu i teraz, przeł. C. Zalewski, Kraków 2018.

Gniazdowski A., Komunitaryzm Edyty Stein według Alasdaira MacIntyre’a, w: Wobec doświadczenia. Fenomen Edyty Stein, cz. 2, red. A. Grzegorczyk, M. Grzywacz, P. Jakubowski, R. Koschany, Poznań 2017, s. 121-123.

Grzegorczyk A., Bóg i wiara w filozofii Edyty Stein, w: Demitologizacja, świadectwo, dialog. Niemiecka filozofia religii, red. J. Barcik, G. Chrzanowski OP, Kraków 2008, s. 179-201.

Grzegorczyk A., Cierpienie duszy według Fiodora Dostojewskiego i Edyty Stein, w: Fenomen cierpienia, red. S. Cofta, A. Grzegorczyk, M. Musielak, Poznań 2019, s. 189-211.

Grzegorczyk A., Edyta Stein, Simone Weil i Hannah Arendt wobec zła, w: A. Grzegorczyk, Źródła sensu w humanistyce, Kęty 2018, s. 95-108.

Grzegorczyk A., Europejskie konteksty Edyty Stein, w: Fenomen ducha Europy, Poznań 2010, s. 121-137.

Grzegorczyk A., Filozofia światła Edyty Stein, Poznań 2004.

Grzegorczyk A., Kobieta Światła i Kobieta Buntu, w: A. Grzegorczyk, Filozofia światła Edyty Stein, Poznań 2004, s. 228-250.

Grzegorczyk A., Personalizm Edyty Stein wobec współczesnego posthumanizmu, w: Splendor personae. Święta Edyta Stein - patronka Europy, red. B. Gołkowska, Warszawa 2019, s. 161-188.

Grzegorczyk A., Ponad granicami. Uniwersalizm Edyty Stein, Poznań 2010

Grzegorczyk A., Ponad kulturami. Uniwersalizm Edyty Stein, Poznań 2010.

Grzegorczyk A., Prawda literacka a prawda objawiona w „Fauście” Goethego i poezji św. Jana od Krzyża, w: A. Grzegorczyk, Obecność wartości, Poznań 2010, s. 47-67. Grzegorczyk A., Prawda, która cierpi. Refleksje na temat filozofii mistycznej Edyty Stein, w: Europejskie dziedzictwo Edyty Stein, Wrocław 2005, s. 15-23.

Grzegorczyk A., Stein contra Heidegger, w: A. Grzegorczyk, Obecność wartości, Poznań 2010, s. 179-186.

Grzegorczyk A., W mądrości Krzyża i blasku Zmartwychwstania. Edyta Stein i Maria Hiszpańska Neumann, Poznań 2019.

Jan Paweł II, Adhortacja apostolska Ecclesia in Europa (28.06.2003), (https://opoka.org. $\mathrm{pl} /$ biblioteka/W/WP/jan_pawel_ii/adhortacje/europa_28062003.html (29.12.2020). 
Jan Paweł II, List apostolski motu proprio Spes aedificandi ogłaszający św. Brygidę Szwedzką, św. Katarzynę ze Sieny i św. Teresę Benedyktę od Krzyża współpatronkami Europy, „L'Osservatore Romano” (wyd. pol.) 20 (1999) nr 12 (218), https://opoka.org.pl/biblioteka/W/WP/jan_pawel_ii/motu/patronki_europy.html (29.12.2020).

Jan Paweł II, Świadectwo błogosławionej Edyty Stein, siostry Benedykty od Krzyża - męczennicy, w: Splendor personae. Święta Edyta Stein - patronka Europy, red. B. Gołkowska, Warszawa 2019, s. 21-25.

Jan Paweł II, Wiara i Krzyż sa nierozdzielne, w: Splendor personae. Święta Edyta Stein patronka Europy, red. B. Gołkowska, Warszawa 2019, s. 30-32.

Jędraszewski M., Tchnąc nowego ducha w Stary Kontynent, w: Fenomen Ducha Europy, red. M. Jędraszewski, M. Loba, D. Jewdokimow, Poznań 2010, s. 105-121.

Kopania J., Nowacka M., Od unieśmiertelniania człowieka do śmierci cywilizacji, w: Ulepszanie człowieka. Perspektywa filozoficzna, red. G. Hołub, P. Duchliński, Kraków 2018, s. 31-71.

Kucharczyk G., Godzina ciemności, http://www.pch24.pl/godzina-ciemnosci-trwalego-pokoju-nie-bedzie-bez-powrotu-do-chrystusa,70496,i.html\#ixzz5yS3DxEf (5.11.2020).

Kucharczyk G., Godzina ciemności. Trwałego pokoju nie będzie bez powrotu do Chrystusa, http://www.pch24.pl/godzina-ciemnosci--trwalego-pokoju-nie-bedzie-bez-powrotu-do-chrystusa,70496,i.html\#ixzz5yS3DxEf (9.11.2020).

List E. Stein do R. Ingardena z 2.06.1918 r., w: Św. Teresa Benedykta od Krzyża/E. Stein, Autoportret $z$ listów, cz. 3: Listy do Romana Ingardena, przeł. M. Klentak-Zabłocka, A. Wajs, Kraków 2003, s. 121.

Machnacz J., Edyta Stein - św. Teresa Benedykta od Krzyża. Osoba, fenomenolog, metafizyk (ontolog), teolog mistyk, świadek (martyr), w: Splendor personae. Święta Edyta Stein - patronka Europy, red. B. Gołkowska, Warszawa 2019, s. 63-94.

MacIntyre A., Edith Stein. A Philosophical Prologue 1913-1922, Lanham-Boulder-New York-Toronto-Plymouth 2006.

Marcel G., L'homme problematique, Paris [1955].

Monticelli R. de, Lascese philosophique. Phenomenologie et platonisme, Paris 1997.

Newman J. H., Ewangelia jako pierwotne źródło ducha ewangelicznego, w: J. H. Newman, Kazania uniwersyteckie, Kraków 2000.

Nietzsche F., Tako rzecze Zaratustra, przeł. W. Berent, Warszawa: Nakład Jakuba Mortkowicza 1908.

Nietzsche F., Wędrowiec i jego cień, przeł. K. Drzewiecki, Kraków 2016.

Norwid C. K., Krzyż i dziecko, w: C. K. Norwid, Pisma wybrane, t. 1: Wiersze, Warszawa 1980, s. 398-399. 
Nota J. H., Edyta Stein a projekt encykliki przeciwko rasizmowi i antysemityzmowi, przeł. J. Zychowicz, „Znak-Idee” $1989 \mathrm{nr}$ 1: Edyta Stein albo filozofia i krzyż, red. P. Taranczewski, K. Tarnowski, H. Woźniakowski, s. 65-8o.

Nuzzo V., Edith Stein ed i filosofi del nostro tempo, Weil e Nietzsche, „Dialegesthai. Rivista telematica di filosofia" 17 (2016) [opublikowany: 30.07.2016 on-line: https:// mondodomani.org/dialegesthai/], https://mondodomani.org/dialegesthai/articoli/ vincenzo-nuzzo-01 (7.11.2020).

Polewska A., Humani generis unitas - projekt antyrasistowskiej encykliki Piusa XI, https://www.researchgate.net/publication/312649299_Humani_generis_unitas_-projekt_antyrasistowskiej_encykliki_Piusa_XI (7.09.2019).

Prokop A. R. Eurofilozoficzny kontekst katolickich konwersji pośród fenomenologów, w: Edyta Stein. Europa i jej tożsamość, red. J. Machnacz, T. Marcinów, K. Serafin, Wrocław 2017, s. 50-63.

Quinzio S., Przegrana Boga?, przeł. M. Bielawski, Kraków-Dębica 2008.

Stein E., Au pied de la Croix, w: E. Stein, Malgré la nuit: poésies complètes, trad. C. Rastoin, Genève 2002, s. 79-83.

Stein E., Budowa osoby ludzkiej. Wykład z antropologii filozoficznej, przeł. G. Sowiński, Kraków 2015.

Stein E., Czym jest człowiek? Antropologia teologiczna, przeł. G. Sowiński, Kraków 2012.

Stein E., Dzieje pewnej żydowskiej rodziny, przeł. I. Adamska OCD, Kraków2005.

Stein E., Kobieta. Pytania i refleksje, przeł. W. Szymona OP, Kraków 2015.

Stein E., Myśli Edyty Stein, wybór M. Hoffmann, Warszawa 1995.

Stein E., Natura i nadnatura w „Fauście” Goethego, w: E. Stein, Twierdza duchowa, przeł. I. Adamska OCD, Poznań 1998, s. 123-135.

Stein E., A ja pozostaję $z$ wami. Z nowenny na Zesłanie Ducha Świętego, przeł. Z. Naumowicz, w: J. I. Adamska OCD, Mądrość Miłości, Tczew-Peplin 1998, s. 256-259.

Stein E., Qui es-tu, douce Lumière, w: E. Stein, Malgré la nuit: poésies complètes, trad. C. Rastoin, Genève 2002, s. 121-129.

Stein E., Le signe de la Croix, w: E. Stein, Malgré la nuit: poésies complètes, trad. C. Rastoin, Genève 2002, s. 65-71.

Stein E., Spór o prawdę istnienia. Listy Edith Stein do Romana Ingardena, przeł. M. Klentak-Zabłocka, A. Wajs, Warszawa 1994.

Stein E., Wiedza Krzyża. Studium o św. Janie od Krzyża (Kreuzeswissenschaft. Studie über Johannes vom Kreuz), tłum. I. J. Adamska OCD, G. Sowinski, Kraków 2013.

Suchocka H., Europa a świadectwo Edyty Stein, „Zeszyty Naukowe Centrum Badań im. Edyty Stein" 2014 nr 11: Fenomen Edyty Stein. Das Phänomen Edith Stein, s. 345-354. Święta Teresa od Jezusa, Listy, Kraków 2008. 
Tatar M., Europa bez krzyża - krzyż przyszłościa Europy, w: Splendor personae. Święta Edyta Stein - patronka Europy, red. B. Gołkowska, Warszawa 2019, s. 103-128. Tischner J., Edyta Stein. Filozof i świadek epoki, red. ks. J. Piecuch, Opole 1997. Waldenfels H., Ukrzyżowany i religie świata, przeł. P. Pachciarek, Warszawa 1985. Weigel G., Katedra i sześcian. Europa, Stany Zjednoczone i polityka bez Boga, Poznań 2016.

Witczyk H., Jezus i Paweł a początki chrześcijaństwa, http://biblista.pl/ukryte/czytelnia-biblijna/4456-jezus-i-pawe-ks-h-witczyk.html (2.09.2019). 